\title{
On Cultivation of Legal Personnel Concerning Foreign Affairs in China---Using Legal English Education as the Breakthrough
}

\author{
Zhu Jie \\ School of Humanities, China University of Political Science and Law, Beijing, China
}

\section{Email address:}

janet920@126.com

\section{To cite this article:}

Zhu Jie. On Cultivation of Legal Personnel Concerning Foreign Affairs in China---Using Legal English Education as the Breakthrough. International Journal of Secondary Education. Vol. 7, No. 2, 2019, pp. 44-50. doi: 10.11648/j.ijsedu.20190702.14

Received: April 28, 2019; Accepted: May 31, 2019; Published: July 4, 2019

\begin{abstract}
With China's active participation in international competition, Chinese market is in need of the legal personnel concerning foreign affairs who are both good at English and law. Therefore the traditional "Law + English" teaching mode can hardly undertake the training task, so the reform is necessary. With deep analysis of market demand as well as the establishment of completed course system, the legal English teaching should be included under the background of education for legal personnel concerning foreign affairs, and varied colleges could design their own courses at different levels based on their own characteristic and the capabilities of students; the National Legal English Certificate Test should be introduced as the professional evaluation for legal personnel concerning foreign affairs; legal professionalism cultivation should also be carried out during the whole teaching process in order to build up moral diathesis and professional ethics for students.
\end{abstract}

Keywords: Legal English Education, Legal Personnel Concerning Foreign Affairs, Market Demands

\section{Introduction}

During the development of international relationship, the process of the civilization is the transition from violence to diplomacy, from diplomacy to law. With the globalization, the politics, economy and culture of countries all over the world inevitably intertwined together, and the conflicts has always been with cooperation and mutual benefit. All the problems during China's opening up, no matter political level, economic level or citizen level, should be solved through legal channel eventually. Globalization infinitely enlarged connotation of "law", since many problems are ultimately legal issues. Globalization has promoted "legal globalization", which meanwhile requires "globalization of legal personnel". However, due to the failure of current legal personnel education, there are few interdisciplinary talents could conduct foreign legal service, which block China's opening up to outside world and contribution to the world economy. Meanwhile, although Chinese kids learn English even in kindergartens, "at present, in various foreign-related issues, the compound high-end talents of foreign studies are limited, not to mention the international talents who are good at foreign languages and directly participate in the international cooperation and competition" [1]. The urgent demand of market and national macro policies have given severe challenge and requirement for college education on interdisciplinary talents, and the time grants historical mission of fostering the legal personnel concerning foreign affairs who are both good at English and law to the higher education.

\section{Literature Review}

Due to the urgent demand of legal personnel concerning foreign affairs as well as the higher education reform in China, many scholars have already made fruitful researches on the related topics which serve as the foundation for my study. As the doctoral supervisor in China University of Political Science and Law, Professor Zhang Falian specializes in cultivation of legal English talents and legal English teaching, who published several papers with high academic value on related issue. In his paper "On Cultivation Mechanism of Compound Talents of Legal English in New Era", he proposes a general idea of building legal English talents training mechanism for a new era, elaborating the specific path for the 
construction of talents training mechanism from the aspects of talent training objectives, curriculum design, teaching staff development, and legal English talents evaluation mechanism [2]; in "Cultivation of Legal English Talents Seen from National Strategies", he suggests from the perspective of talents cultivation, globalization brings legal English new contents and requires that legal English talents be international, interdisiplinary and application-oriented. To cultivate talents of this type schools of higher education need to follow a multi-dimentional and long-term course of development and be guided by the principle of "diversification", "profesionalization" and "with characteristics" [3]; and in his another paper "On systematic Design of Compound Talents of Legal English Cultivation Mode", he suggests schools of foreign studies should take action firstly, actively make full use of legal resource in its university, set up cultivation goal scientifically, enhance the international cooperation, and break down the traditional curriculum mode in order to explore the creative mode for legal English teaching [4].

Many scholors wrote influential papers on college English education reform, such as: in Cai Jigang's paper "Review of Chinese Tertiary English Education: Failure and Lessons", he critisizes English education failed to produce tertiary graduates who have competitive competence in the international arena of economy, science and technology. And the failure could be attributed to its orientation to the teaching English for general purposes rather than for specific purposes, the neglect of English as a tool to communicate in disciplinary studies, the low institutional status of college English teaching and the failure of the government's foreign language requirement to be expressed in tertiary English education policies [5]; in Professor Wang Shouren's paper "Some Thoughts on College English Teaching in China", he summorizes the problems in current college English education, and suggests strengthening college English teaching reform in China, clarifying the mission and task of College English teaching, establishing college English course systems [6]; in the paper "Social Needs and Foreign Languages Faculty Development", Professor Shu Dingfang suggests universities: to promote foreign language curricula is to merge the English Language Department with the Department of College English so that the courses they offer to the target students can be complementary and faculty members can have more opportunities for professional development. The new foreign language community can form different learning units with able leaders and come up with top-level course designs to integrate foreign language courses into the overall university talent development blueprint and to contribute to the internationalization of the university and itself [7].

\section{The Analysis of Chinese Current Situation of Legal Personnel Concerning Foreign Affairs}

With China's active participation into international division of labour, the foreign legal affairs shot up, and the market urgently demands legal personnel concerning foreign affairs to safeguard China's opening up, however the education mode of Chinese colleges is too rough to foster the qualified legal personnel concerning foreign affairs. Therefore through macro policy level, Chinese government actively leads and encourages the colleges to integrate educational resource, to reform the teaching mode, and to cultivate qualified applied and compound legal personnel concerning foreign affairs. At present, with China's active opening up to the outside world, Chinese companies widely take part in the international division of labour, which also brings forward Chinese citizens to gradually go outside to foreign countries, getting along with more and more foreign civil and commercial legal business.

\subsection{The Surge of Chinese Foreign Legal Service}

Under the background of China's participation into world economy, Chinese foreign trade has suffered from serious conflicts, partly due to unfamiliarity with the "rule of game" and trade protectionism of some countries, so Chinese government and enterprises have no option but positively answer the lawsuits, and fight for no measure outcome; besides foreign trade, according to 2017 Statistical Bulletin of China's Outward Foreign Direct Investment [8]: until the end of 2017, stock of China's foreign direct investment was 1.8 trillion US dollar, ranking 2nd all over the world.....the amount of China's FDI ranked 3rd of 158.3 US dollar. While the complication of overseas investment market, the stagnant of related Chinese foreign investment codes, the incompletion of legal protection mechanism of overseas direct investment, as well as the investor's incomprehension to the laws and regulations of investing country, and even the ignorance of the culture and custom of investing country, would bring huge danger to FDI of Chinese enterprises; meanwhile a large amount of Chinese citizens go outside to foreign countries: in 2017, the total amount of China's entry-exit personnel reached to 598 million, year-on-year increase of $4.76 \%$, among them the total amount of Chinese mainland residents entry-exit personnel reached to 292 million, year-on-year increase of $6.73 \%$. Opposite to the rapid growth of outbound population, the personal safety and related rights and interests guarantee of overseas Chinese citizens have turned to be serious day by day. Besides personal security issues, Chinese citizens become in need of foreign legal services for overseas study, investment, immigration, and even violation of law.

\subsection{The Sharp Shortage of Local Legal Personnel Concerning Foreign Affairs}

To the contrast of the market's sharp demand of legal personnel concerning foreign affairs: until 2013, there were only 3000 lawyers specializing in foreign legal affairs, among them no more than 200 lawyers could independently conduct foreign arbitration and cross border lawsuit, and less than 50 lawyers could conduct "anti-dumping, countervailing, measure of safeguard, and special safeguard measures" cases, as well as no more than 20 lawyers could participate in dispute settlement cases in WTO. [9] The investigation data to large 
law offices indicated that even in large-scale law firms, there were few lawyers provide foreign legal services (Figure 1):

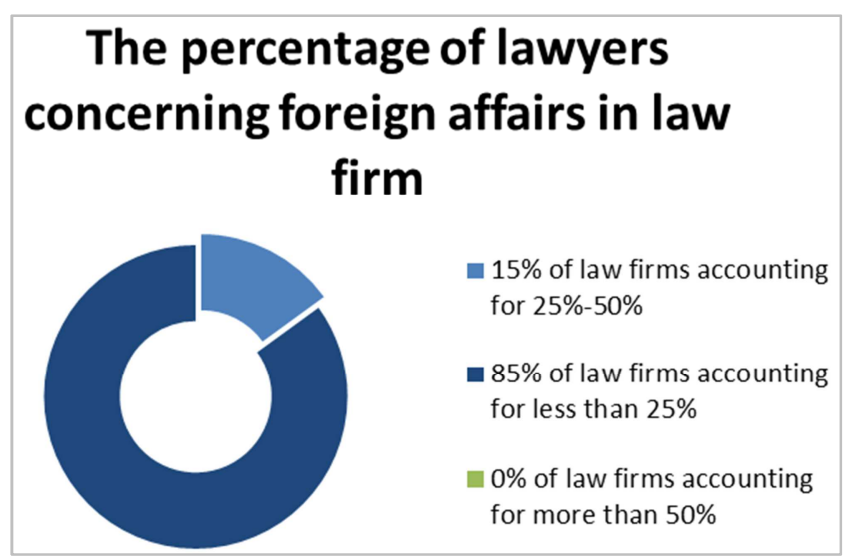

Figure 1. The percentage of lawyers concerning foreign affairs in law firm $^{[2] 75}$.

Therefore, Chinese enterprises and individuals were force to hire foreign lawyers to solve legal issues concerning foreign affairs with high salary: "Even in Shanghai where the legal service market concerning foreign affairs is more advanced, the world top 10 foreign law firms set up offices in Shanghai. Thus the legal services in Shanghai are possessed by these foreign firms, while the local lawyers turn to be 'the underprivileged"'. [10] However, the legal services provided by foreign lawyers can't fully satisfy the demand of Chinese enterprises even paid high, what actually enterprises need is the local lawyers who could provide high level foreign legal services (Figure 2):

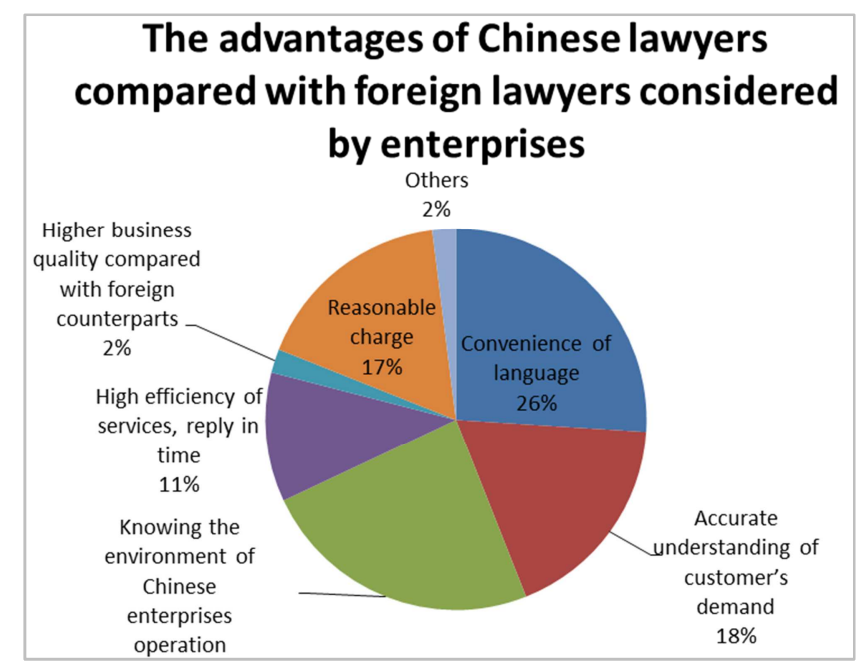

Figure 2. The advantages of Chinese lawyers compared with foreign lawyers considered by enterprises.

\subsection{The Hysteresis of Traditional "Law + English" Teaching Mode}

The compound legal talents education in China may date back as early as 1980 s, but the traditional teaching mode couldn't foster qualified legal personnel concerning foreign affairs based on the recent market demand. There were two types of "law + English" teaching mode: One was category into "English for Special Purposes" (ESP). The textbook was English with 15 to 20 chapters, and each chapter simply introduced British and American legal systems (including brief introduction of legal system, constitution, criminal law, contract law, torts, business law, and etc.). As a course with only 36-72 class periods, the result for thoroughness made the course a mere formality, and students tired of it, which couldn't achieve the expected effects; Another was carrying out bilingual teaching of law, which adopted foreign original textbook directly, and taught professional law course in English. But legal language in Britain and American has its unique vocabularies, sentence patterns and texts, which were hard to understand merely by referring dictionary. Without professional training, even English natives felt frustrated in front of the esoteric articles, not to mention Chinese students as the second language learners. If it was difficult to follow the language, it would be even harder to study the foreign legal knowledge. It's quite obvious the teaching objective of both modes was over-ambitious, and the teaching process turned to a mere formality which led to the waste of educational resource, and was impossible to foster the qualified legal personnel concerning foreign affairs. So the reform which includes fostering plan, majors, and subject construction is imperative, and should closely link with reality as well as the market demand.

\section{The Legal English Education ---As the Breakthrough to Foster Legal Personnel Concerning Foreign Affairs}

In order to meet the urgent market demand, the new legal English discipline which mainly teaches American law in English has created, shifting the backward "law + English" talents fostering mode. The establishment and completion of the new mode could benefit the harmonious integration and coordinate development of both disciplines, optimize the educational resource in colleges, and make full use of the advanced majors in college in order to foster high level, multi-tiered legal personnel concerning foreign affairs who may satisfy the refined market requirement.

\subsection{Using Talents Who Are Both Good at English and Law as the Fostering Objective of the Legal Personnel Concerning Foreign Affairs}

Since English is the world universal language and the leading role of common law, especial American law in international affairs, the recent fostering objective of legal personnel concerning foreign affairs is to educate compound talents who are "both good at English and law". If fostering legal personnel concerning foreign affairs could serve as the "breakthrough", legal English is the "breakthrough" to foster legal personnel concerning foreign affairs, and American law is "the road ahead": 


\subsubsection{The Importance of English in Foreign Legal Affairs}

With globalization, the concept of "global village" has been widely accepted all over the world, and the obligation to adjust social relationship shifting from sovereign states to international organizations, and international conventions gradually turned to important component of national source of law: "until now, China took part in more than 100 inter-governmental organizations, and signed almost 300 multilateral international treaties" [11] (Figure 3):

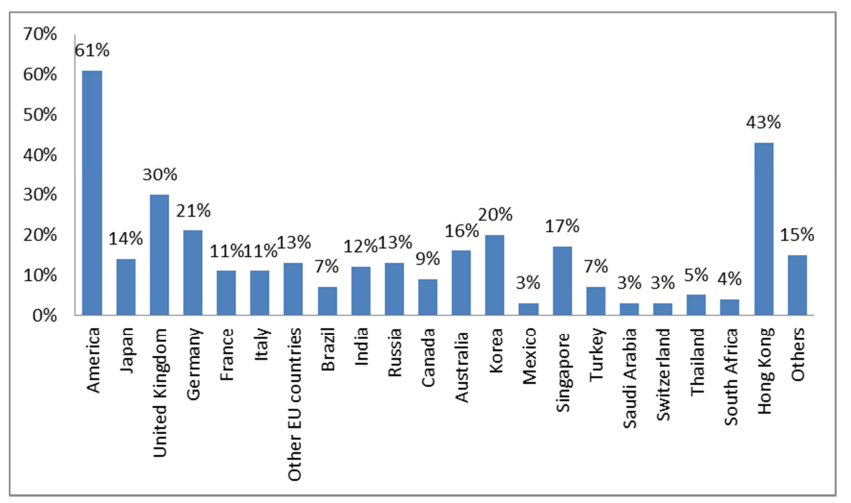

Figure 3. The countries and regions where Chinese lawyer could provide legal service $[2]^{74}$.

Among the 21 countries or regions, 10 of their official languages are English, and the business volume accounted for more than $10 \%$. And the survey of working language of lawyers concerning foreign affairs indicated that (Figure 4):

\section{The working languages of lawyers concerning foreign affairs}

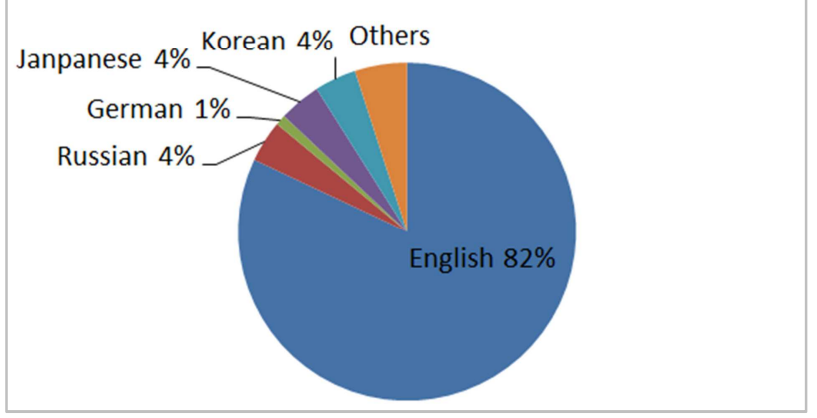

Figure 4. The working languages of lawyers concerning foreign affairs $[2]^{74}$.

Among 229 foreign law firms in China, "there are 142 firms from American and Britain setting up their branches, occupying $62 \%$ of all foreign branches in China". It's indicated together with the data in figure 3: the business volume of Chinese lawyers towards both America and Britain was obviously more than other countries', and the major commercial and trade partners of Chinese enterprises are from these two powerful countries, and English is no doubt mainstream legal languages. Before the education of legal personnel concerning foreign affairs could develop to include languages of all countries and regions having business with
China, it's the top priority to concentrate teaching resource, and foster legal personnel concerning foreign affairs who are both good at English and law.

\subsubsection{The Importance of American Law in Foreign Legal Affairs}

To the legal personnel concerning foreign affairs, "both good at English and law" means besides knowing Chinese law, it's necessary to master foreign law, while the extension of foreign law is too broad lacking guiding significance. It's impossible to study all as the applied talents conducting legal practice, but to choose the most influential, widely applied, and systematically completed foreign laws--- American law is no doubt best choice:

First of all, American law is the most completed and well developed legal system, which has most influential power worldwide, and is valuable to learn from the jurisprudence research angle. As we all know, American law is the classical representative in common law system with broad contents, includes both traditional case law and new written law; united federal law and states law. Meanwhile, American law is worldwide influential, and is meaningful to learn because not only many countries are researching and borrowing from American law, but also a lot of international conventions refer to the ideas, principles and rules of American law too. [12]

Secondly, both China and America has built up the close economic tie since China's entry of WTO: China is the biggest trading partner of America, third commodity export market and biggest importing country; America is the second trading partner and biggest importing country. With economic mutual benefit, the litigation and non-litigation legal business has increased sharply. figure 3 indicates that among all the foreign legal business Chinese lawyers conducted, $61 \%$ were with America which is much higher than with other countries and regions.

Finally, America attempts to control the world economy through legal output. What America amazing the world is the strong top-level design of its legal system. From "world police" to "global judge", relying on economic foundation, refined legal system output, as well as regulated management, America controlled $80 \%$ of the cross-border enterprises, which is the real competitive power of America [13]. By making full use of Export Control Regulations, Prevention of Bribery Ordinance, Sarbanes-Oxley Acts, America reasonably and legally controlled cross-border enterprises which have no relationships with America under the name of justice, incorruptibility and fairness, covering the whole world. In other words, cross-border enterprises between China and any country may be controlled by America, which means China couldn't avoid American "Long arm jurisdiction" if insisting on opening up policy. The only thing we could do is to know American legal system at all round, then analyze and study on countermeasure based on vast cases.

\subsection{The Legal English Course Design Satisfying Market Demand}

Due to the current shortage of legal personnel concerning foreign affairs, varied colleges are eager to foster the 
compound talents who are both good at English and law to meet the market demand. As the important fruit of college English education reform, the legal English course has received broad emphasis and development. Although the name of the course has presumably long been in China, the new time background and market demand give it new intension and mission. Even the course belongs to inter-disciplinary course, but it isn't simply equivalent to "law + English" with the necessary nature as a systematic discipline. Under the background of market's urgent demand of local legal personnel concerning foreign affairs and more foreign law firms enter Chinese market, the colleges need to design market oriented legal English curriculum system with its college's characteristics by clarifying the teaching objective, regulating curriculum system, and fostering qualified teaching staff.

\subsubsection{The Linguistic Nature of Legal English Course}

The definition of legal language by Oxford Dictionary of Law is: Confront of the highly professional linguistic mode, even for English natives, it's essential to learn the language of law as well as how to use that specific language in legal practise. In other words, it's necessary to start from legal language in common law system no matter to learn American legal system or English: The objective of legal English teaching should be improving the real application capability of English, and to learn how to solve legislation, jurisdiction, litigation and non-litigation legal affairs, as well as legal academic research.

In many colleges, legal English course has coexisted with general English course, bilingual course and other course modes, so it's unavoidable to confuse the nature and type of the course. Based on the disciplinary characteristics of legal English, as the important branch of ESP, legal English course should belong to English course system, which is the advanced course for general English as well as the "preparatory level" of bilingual course. After all, legal English course is an English course, it's improper to teaching legal knowledge by English without solid linguistic foundation. During the process of legal English teaching, it's necessary to strengthen the training intensity and exam proportion of the output skills, such as: listening, speaking, reading, writing, translation, and etc., in order to equip students with solid foundation for legal English practice and foreign legal affairs in the future. While the proportions of English study is the whole curriculum system isn't constant, it could adjust based on students' English level and different teaching periods (Figure 5):

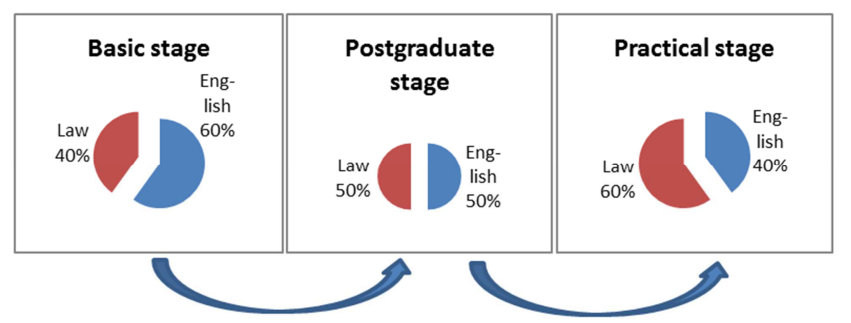

Figure 5. Proportions of law and English study.

\subsubsection{The Design of Hierarchical Legal English Course}

Chinese demands for legal talents are multi-directional and multiple-level, without all-round consideration, it may cause varied college's blind development and repeated construction of the course, which will not only damage the tentative legal English curriculum, but also bungle national development, and waste educational resource, as well as mislead students. More than 600 law schools in China have their own regional and school-based characteristics, varied in educational resource, disciplinary basis, and students' capabilities, the "one-size-fits-all" curriculum construction mode fails to satisfy different teaching units. Therefore, based on real situation, the teaching main body of legal English could be divided into two types:

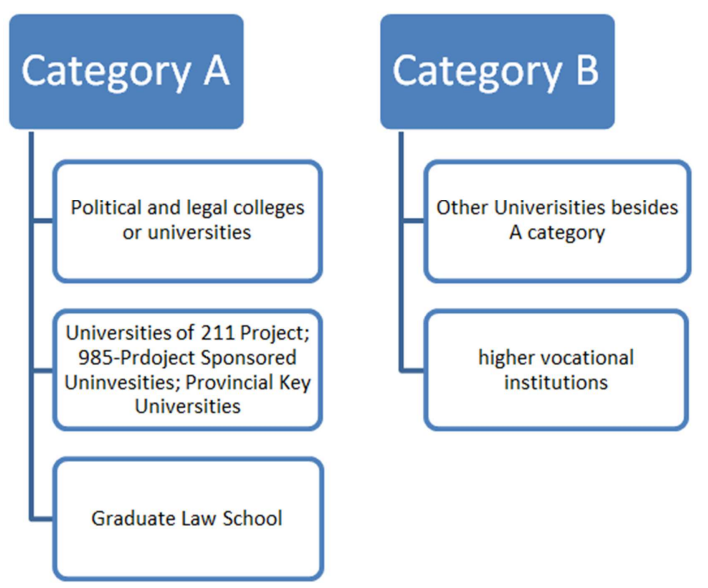

Figure 6. The division of teaching main body of legal English in Chinese colleges.

Category A needs to achieve the goal of advanced period of legal English teaching; Category B needs to reach the goal of fundamental period of legal English teaching which is the minimum requirement of college legal English to students. As regards the students in the same college with different foundations and levels, their teaching objectives also need to be further divided:

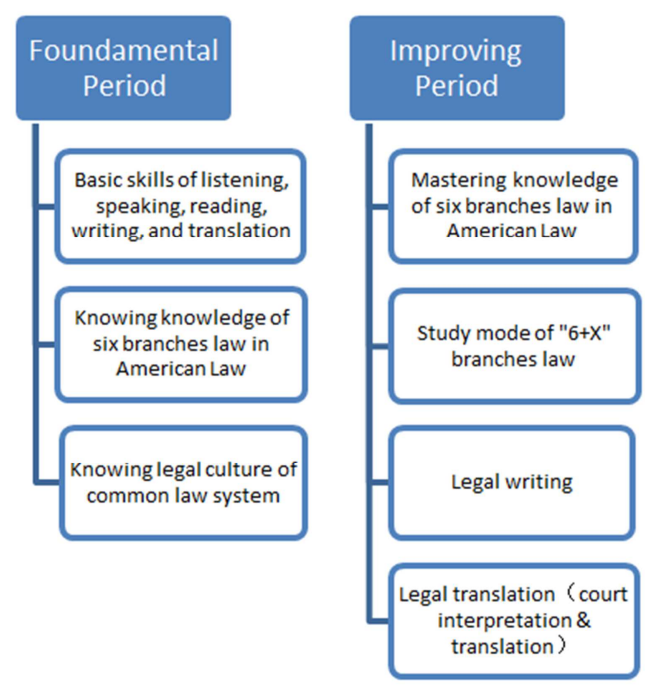

Figure 7. Division of legal English teaching objectives in Chinese colleges. 
The six fundamental American branches law includes: constitution, contract law, property law, torts, evidence law, criminal law/ criminal procedural law, which are the major branches law to support American legal system, as well as the basic legal knowledge that students need to master; " $6+\mathrm{X} "$ means: besides those six fundamental legal sectors, students may learn one or two branches law relating their professions and research field, such as: intellectual law, corporation law, international law, and etc. And the "X" should combine market demands and school-based characteristics so as to foster the compound talents both mastering solid legal knowledge and specializing in foreign legal service.

\subsubsection{The Qualification Evaluation for Legal Personnel Concerning Foreign Affairs}

Due to the professionalism and complexity of legal personnel concerning foreign affairs, the ordinary "Qualification Examination for Legal Practitioners" and "College English Test Band 4/6" can't correct evaluate the qualification of the legal personnel to conduct foreign affairs. Without unified standard in market, it easily leads to the market chaos of foreign legal service, and brings damage to the clients as well as the competition with foreign law firms. Therefore, market also needs the authoritative certificate to the qualification of those legal personnel when colleges promote legal English education---"National Legal English Certificate Test" may hold this task.

The committee of the test entrusts China University of Political Science and Law and Beijing Foreign Studies University to organize the specific works, which is the only professional test to assess the qualification of the examinees when conducting foreign legal affairs. The question types and contents are similar to American Bar Exam, and emphasize on the characteristics of the legal English application by adding legal English translation in accordance with the real practice in China, which has received acknowledgement of some American law schools. Since its introduction in 2008, LEC has become the authority to prove the qualification of professional English capability of legal personnel concerning foreign affairs with its scientific design of test and the overall good reputation and credibility [14]. This certificate could provide reference to the employing unit and enterprises or individuals who demand foreign legal services, as well as regulate the related market. Especially under the background that ministry of education hasn't made any detailed guidance yet, and some colleges opened legal English course blindly, LEC could serve as the "baton" of the teaching objective, mode and contents of legal English course, the pass rates is one of the key index to evaluate the teaching result of legal English course in a certain college as well.

\subsubsection{The Fostering of Legal Profession Attainment}

As the legal personnel who hold the legal weapon to defend fairness and justice, their daily works are reading boring articles and solving technical legal affairs, but their wisdom above the technical level are in need: to find out the truth through complicated affairs with precise judgment; to provide cautious suggestion to solve tough problems; and to concern social welfare, as well as serve the public. So legal professional accomplishment education should adhere to every teaching process, and influence students imperceptibly in order to build up correct value direction. Although market's demands for the techniques of legal personnel concerning foreign affairs are changeable, the pursuit to legal personnel's virtuous legal professional accomplishment is eternal.

Therefore, as regards the fostering of legal personnel concerning foreign affairs, it's necessary to enhance the students' general education and expand the knowledge besides profession; the legal English teachers need to add legal philosophy, logical thinking, legal culture, and other knowledge in the teaching process in order to foster students' precise legal thinking, analyzing situation both at home and abroad rationally and objectively, strengthening sense of social responsibility, building up good moral quality and professional accomplishment, otherwise legal majors may have the chance to descend to delicate egoists, and pursue self-interests through legal skills so as to bring harm to society. All in all, "legal personnel seemed to have the extreme favor towards the system, but the cruel reality told us: even with the good system, the law easily turned to the waste paper without profound humanistic spirit and the fundamental conscience, not to mention operated smoothly which was only the fantasy. "This brings higher requirement for legal English teachers who need to possess great morality and broad vision so that they could lead students to become the legal talents with both ability and moral integrity.

\section{Conclusion}

In the new situation, the national development raises the new challenge for intellectual support of institution of higher education, and the new requirements are proposed based on its demand to talents. In response, the talent cultivation mode should adjust accordingly. [15] The nature of law is to solve contradiction, and mediate conflict, which has the strong facticity. The fostering of legal talents, especially legal personnel concerning foreign affairs, should keep pace with time, and closely relate with practice. As the practical crossing discipline combined with both jurisprudence and English linguistics, legal English education should develop with the driving force of the market, and foster the qualified legal talents to satisfy its demand. Therefore, the legal English education should be involved into the background of Chinese reform and opening up, and conduct deep analysis of market demand, so as to encourage different colleges to set up their curriculums on their own characteristics and students' level flexibly on the basis of the completed establishment of the curriculum system.

"This paper is the stage achievement of 2018 Philosophy and Social Science Planning Project in Henan Province "On 'Team Teaching' of Legal English Translation” (2018BYY002); 2018 PhD Innovation Practice Project in China University of Political Science and Law "The Teaching Research on 
curriculum of 'English Legal Literature'”' (2018BSCX42)".

\section{References}

[1] Zhong Weihe, Wang Weiwei, Huang Enmou, Language-in-Education Planning from the Perspective of National Foreign Language Capacity Building, Chinese Journal of Language Policy and Planning, 2016, 1 (05), 45-51.

[2] Zhang Falian, On Cultivation Mechanism of Compound Talents of Legal English in New Era, Foreign Language Education, 2018, 39 (03): 44-47.

[3] Li Fengxia, Zhang Falian, Xu Wenbin, Cultivation of Legal English Talents Seen from National Strategies, Foreign Language and Literature, 2015, 31 (05): 134-137.

[4] Zhang Falian, On systematic Design of Compound Talents of Legal English Cultivation Mode, Adult Education in China, 2009 (9): 135-136.

[5] Cai Jigang, Review of Chinese Tertiary English Education: Failure and Lessons, Journal of Northeast normal University (philosophy and Social Sciences Edition), 2017 (05): 1-7.

[6] Wang Shouren, Some Thoughts on College English Teaching in China, Foreign Language Learning Theory and Practice, 2011 (01): 1-5.

[7] Shu Dingfang, Social Needs and Foreign Languages Faculty Development, Foreign Languages in China, 2017, 14 (01): 22-25.
[8] Department of Commerce of People's Republic of China, N. S. B., State Administration of Exchange Control 2017 Statistical Bulletin of China's Outward Foreign Direct Investment. 2018 (9).

[9] Leng Shuai, etc. The analysis of Chinese foreign legal service. Chinese Lawyer (Part I). 2017 (05): 76.

[10] Tang Bo, etc. The legal education reform under free trade zone construction. Shanghai: People's Publishing House of Shanghai, 2015: 54.

[11] Wei Mingjie, 60 years of China and international treaty. Shanghai: The 7th academic conference collection of social sciences circle in Shanghai. 2009: 61-72.

[12] Zhang Falian. College Legal English. Beijing: Foreign Language Teaching and Research Press. 2014: 9.

[13] Jian Jun. In the name of father---How could American law control $80 \%$ of enterprises worldwide? Corporate legal works (07). 2016: 52-53.

[14] Zhang Falian, On Cultivation of Legal Personnel Concerning Foreign Affairs under the "Belt and Road Initiative", Legal Daily, December $6^{\text {th }}, 2017$.

[15] Yuan Xiaolu, Zhao Juan, Appeals and Solutions to Cultural Awareness Cultivation in Foreign Language Education in the Background of "The Silk Road Economic Belt and the 21st-Century Maritime Silk Road Initiative", Journal of Xi'an International Studies University, 2017, 25 (03), 69-72. 